\title{
Phylogeography of the banded
} butterflyfish, Chaetodon striatus, indicates high connectivity between biogeographic provinces and ecosystems a in the western Atlantic

Correspondence:

Sergio R. Floeter sergio.floeter@ufsc.br

Submitted June 2, 2019

Accepted January 4, 2020

by Fernando Gibran

Published April 20, 2020
Online version ISSN 1982-0224

Print version ISSN 1679-6225

Neotrop. Ichthyol.

vol. 18, no. 1, Maringá 2020

Epub, Apr 17, 2020

\author{
${ }^{\oplus}$ Ana M.R. Liedke ${ }^{1,2}$, ${ }^{\oplus}$ Hudson T. Pinheiro ${ }^{3,4},{ }^{\bullet}$ Sergio R. Floeter ${ }^{2}$ and \\ ${ }^{\oplus}$ Giacomo Bernardi ${ }^{3}$
}

Among the four butterflyfishes of the genus Chaetodon present in the western Atlantic, the banded butterflyfish Chaetodon striatus has the largest distribution range, spanning 44 degrees of latitude (from Massachusetts, USA to Santa Catarina, Brazil). Although the ecology of the banded butterflyfish has been well studied over its entire range, nothing is known about its phylogeography and how biogeographic barriers structure its populations. To assess the level of genetic connectivity among populations from distinct biogeographic provinces and environmental conditions, we collected samples from seven localities: Puerto Rico, in the Caribbean, and Tamandaré, Salvador, Abrolhos, Trindade Island, Arraial do Cabo and Florianópolis, in Brazil. One nuclear ( rag 2) and two mitochondrial (control region and $c y t b$ ) molecular markers were sequenced. Our findings are consistent with a recent population expansion, around 30-120 thousand years ago, which was found for all populations. Haplotype network analyses point to the Caribbean as a refugium before the population expansion. Results show no geographic pattern of genetic diversity. Indeed, a lack of population structure was found and no isolation was observed across oceanographic barriers, as well as between coral and rocky reef ecosystems. Furthermore, no directionality in the migration pattern was found among populations. Since ecological and environmental characteristics are very diverse across such a vast geographic range, the lack of genetic differentiation suggests that C. striatus evolved ecological plasticity rather than local adaptation in the western Atlantic.

Keywords: Biogeography, Evolution, Mitochondrial Genes, Nuclear Genes, Reef Fish.

\footnotetext{
1 Programa de Pós Graduação em Ecologia e Conservação, Universidade Federal do Paraná, 81531-990 Curitiba, PR, Brazil. analiedke@gmail.com

2 Departamento de Ecologia e Zoologia, Universidade Federal de Santa Catarina, 88010-970 Florianópolis, SC, Brazil. sergio.floeter@ufsc.br

3 Department of Ecology and Evolutionary Biology, University of California Santa Cruz, 100 Shaffer Road, 95064 Santa Cruz, CA, USA. bernardi@ucsc.edu

4 California Academy of Sciences, 94118 San Francisco, CA, USA. htpinheiro@gmail.com
} 
O peixe-borboleta listrado, Chaetodon striatus, possui a maior distribuição geográfica dentre as quatro espécies de peixes-borboleta do gênero Chaetodon presentes no Oceano Atlântico Ocidental, abrangendo $44^{\circ}$ de latitude (entre Massachusetts, EUA até o sul do Brasil). A ecologia alimentar desta espécie é bastante conhecida, considerando a ampla distribuição, porém, pouco se sabe sobre a filogeografia e como as barreiras biogeográficas estruturam as populações. Para acessar a conectividade genética entre as populações de diferentes províncias biogeográficas e diferentes condições ambientais, foram coletadas amostras de sete localidades: Porto Rico, no Caribe, e Tamandaré, Salvador, Abrolhos, Ilha da Trindade, Arraial do Cabo e Florianópolis, no Brasil. Foram sequenciados um gene nuclear $(\operatorname{rag} 2)$ e dois genes mitocondriais (região controle e cit B). Para todas as populações, foi identificada uma expansão populacional recente, em torno de 30-120 mil anos atrás. A análise de rede de haplótipos sugere que o Caribe serviu como refúgio antes desta expansão populacional. Os resultados indicam que não há padrão geográfico de diversidade genética. Apesar da existência de barreiras oceanográficas e diferenças na constituição dos recifes (rochosos e coralíneos), não foi encontrada estruturação populacional. Também, não encontramos padrão na direção de migração entre as populações. Os resultados sugerem que C. striatus apresenta plasticidade ecológica, uma vez que não há diferenciação genética entre as populações que habitam ecossistemas tão diferentes ao longo da ampla distribuição no Atlântico Ocidental.

Palavras-chave: Biogeografia, Evolução, Genes Mitocondriais, Genes Nucleares, Peixes Recifais.

\section{INTRODUCTION}

The number of studies on genetic connectivity of marine organisms has increased in the last decades (e.g., Jones et al., 2007; Eble et al., 2015), mainly due to their importance for understanding biogeographic patterns (Rocha et al., 2008) and for management and conservation (Palumbi, 2003, 2004). Many organisms associated with reef habitats are relatively sedentary as adults, dispersing primarily during the larval phase (Leis, 1991). Dispersal potential can be related to spawning strategy (e.g, pelagic $v$ s. demersal), pelagic larval duration (PLD), and rafting ability (Luiz et al., 2013). However, geographic barriers and ecological constraints can limit dispersal, leading to self-sustained and genetically structured populations, even in species with extensive PLDs (Planes, 1998; Almany et al., 2007; Jones et al., 2007; Selkoe, Toonen, 2011).

Several reef fishes are widely distributed along the western Atlantic, but for most of them it is unclear whether there is contemporary gene flow among biogeographic provinces or if barriers are restricting it. For example, the Amazon plume is a wellknown barrier isolating Caribbean and Brazilian Provinces (Rocha, 2003; Floeter et al., 2008). The remoteness of oceanic islands also isolates many populations in the southwestern Atlantic (Neves et al., 2016; Pinheiro et al., 2017; Dias et al., 2019). Water 
temperature and reef formation (e.g, coral and rocky reefs) are also known as ecological drivers acting synergistically to separate populations from northern and southern waters of the southwestern Atlantic (Santos et al., 2006; Van Tassell et al., 2015; Pinheiro et al., 2018). Thus, depending on the strength of such barriers, peripheral populations may exhibit lower genetic diversity as a consequence of smaller effective population sizes and isolation (Eckert et al., 2008).

Butterflyfishes (Chaetodontidae) have a circumglobal distribution, being present in all tropical and subtropical oceans and are among the most conspicuous fishes on reefs, comprising around 134 species. The vast majority of species (around 90\%) inhabits the Indo-Pacific (Nelson, 2006; Pratchett et al., 2014). In the western Atlantic Ocean there are only nine species, mostly found in the Caribbean. The banded butterflyfish Chaetodon striatus Linnaeus, 1758 has a wide distribution, with vagrant individuals found as far north as Massachusetts, and established populations from the coral reefs of the Greater Caribbean southwards to the rocky reefs of the southern Brazilian coast $\left(27^{\circ} \mathrm{S}\right)$ (CarvalhoFilho, 1999; Floeter et al., 2008; Anderson et al., 2015; Pinheiro et al., 2018). Studies that focused on feeding habits and gut contents showed that this species is considered a noncoral generalist feeder, demonstrating plasticity in diet and no selectivity pattern across its distribution range (Liedke et al., 2016, 2018).

Like for other butterflyfishes, the pelagic larval duration (PLD) of C. striatus lasts between 32-52 days (Booth, Parkinson, 2011; Leis, Yerman, 2012). Despite long PLDs, Indo-Pacific butterflyfish populations have been shown to present a range of low to high genetic structure (McMillan et al., 1999; Craig et al., 2010; Lawton et al., 2011; DiBattista et al., 2012; Messmer et al., 2012). In the western Atlantic, no previous studies have investigated the influence of biogeographic barriers and ecological drivers on the structure of butterflyfish populations.

To investigate the phylogeography of the banded butterflyfish C. striatus, we used mitochondrial and nuclear molecular markers to evaluate the following questions:

1) Is genetic diversity different among populations? We predict that the Caribbean population should have higher genetic diversity than peripheral populations, since this region is postulated as being the center of origin and accumulation of species in the Atlantic (Rocha et al., 2008).

2) How did population size in different populations change through time? Some populations in the western Atlantic show a recent increase in population size, which may be related to sea level fluctuations during the Pleistocene (Silva et al., 2015).

3) Do the western Atlantic biogeographic barriers and different ecosystems influence the genetic structure of the studied populations? Here we expect a strong genetic signature between Caribbean and Brazilian populations, since the Orinoco/Amazon barrier has been suggested as a driver of speciation and vicariant agent for several coastal taxa (Rocha, 2003; Rocha et al., 2008; Floeter et al., 2008; Cunha et al., 2014). The San Francisco River has also been pointed as a potential barrier diverging sub-provinces along the Brazilian coast (Pinheiro et al., 2018). We also expect genetic structure between oceanic islands and coastal populations, since the islands isolation has also driven the differentiation of many insular species (Neves et al., 2016; Pinheiro et al., 2017; Dias et al., 2019). Moreover, as the water temperature and type of ecosystem influence ecological speciation in the western Atlantic (Rocha et al., 2005; Pinheiro et al., 2018), we may expect some genetic structure between coral and rocky reef populations as well. 
4) Is there a pattern of migration between populations? For example, Brazil, as a peripheral province, may be expected to be a sink rather than a source of migrants. The alternate hypothesis is that northward movement is favored across the Orinoco/Amazon barrier by the North Brazilian Current (Luiz et al., 2013).

\section{MATERIALS AND METHODS}

Sampling and DNA extraction. A total of 135 specimens of C. striatus were sampled between January 2010 and February 2011, in seven localities, north (one population) and south (six populations) of the Orinoco/Amazon barrier (Fig. 1): Puerto Rico (PR), in the Caribbean Province $\left(17^{\circ} 56^{\prime} \mathrm{N}, 67^{\circ} 01^{\prime} \mathrm{W}\right)$ (34 specimens) and Tamandare (TAM)

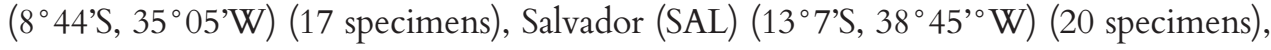

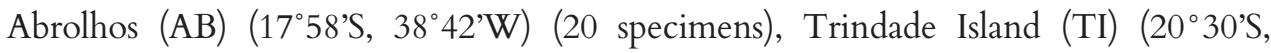
$\left.29^{\circ} 20^{\prime} \mathrm{W}\right)$ (three specimens), Arraial do Cabo (AC) $\left(23^{\circ} \mathrm{S}, 42^{\circ} \mathrm{W}\right)(20$ specimens) and Florianópolis (FLO) $\left(27^{\circ} 17^{\prime} \mathrm{S}, 4^{\circ} 22^{\prime} \mathrm{W}\right)$ (21 specimens) in the Brazilian Province. Muscle tissue was immediately stored in $95 \%$ ethanol at ambient temperature in the field, and later transferred to a freezer at $-20^{\circ} \mathrm{C}$ in the laboratory. Tissues were digested overnight at $55^{\circ} \mathrm{C}$ in $650 \mu \mathrm{L}$ of extraction buffer $(400 \mathrm{mM} \mathrm{NaCl}, 10 \mathrm{mM}$ Tris, $2 \mathrm{mM}$ EDTA, 1\% SDS) and the DNAs were purified by standard chloroform extraction and isopropanol precipitation (Sambrook, Russell, 2001).

Amplification of the 5 ' hypervariable portion of the mitochondrial control region was accomplished with nested PCR's using first the primers CB3L (5'GGC AAA TAG GAA RTA TCA TTC 3') and CR-E (5'CCT GAA GTA GGA ACC AGA TG - Lee et al., 1995) followed by ProL (5'CTA CCT CCA ACT CCC AAA GC 3') and CR-E. Thermal cycling in polymerase chain reactions (PCR) consisted of an initial denaturation step at $94^{\circ} \mathrm{C}$ for $45 \mathrm{sec}$, then 35 cycles of amplification ( $45 \mathrm{sec}$ of denaturation at $94^{\circ} \mathrm{C}, 30 \mathrm{sec}$ of annealing at $52^{\circ} \mathrm{C}$ with the first pair of primers and $54^{\circ} \mathrm{C}$ with the second, and $1 \mathrm{~min}$ of extension at $72^{\circ} \mathrm{C}$ ) and a final extension of $5 \mathrm{~min}$ of $72^{\circ} \mathrm{C}$. In addition, we amplified and sequenced segments of the mitochondrial cytochrome $\mathrm{b}(c y t b)$ using the primers GLUDG-L (5'TGA CTT GAA RAA CCA YCG TTG 3') and CB3H (5'GGC AAA TAG GAA RTA TCA TTC $3^{\prime}$ ) with the following protocol: an initial denaturation step at $94^{\circ} \mathrm{C}$ for $45 \mathrm{sec}$, followed by 35 cycles of $45 \mathrm{sec}$ at $94^{\circ} \mathrm{C}, 45 \mathrm{sec}$ at $54^{\circ} \mathrm{C}$, and $1 \mathrm{~min}$ at $72^{\circ} \mathrm{C}$ and a final extension of $5 \mathrm{~min}$ of $72^{\circ} \mathrm{C}$. The nuclear protein coding recombinationactivating gene $2(\operatorname{rag} 2)$ was amplified with the following primers rag $21 \mathrm{~F}$ ( 5 'GAG GGC CAT CTC CTT CTC CAA 3') and rag 2 9R (5'GAT GGC CTT CCC TCT GTG GGT AC 3'). The thermal cycling was performed by an initial denaturation step at $94^{\circ} \mathrm{C}$ for $45 \mathrm{sec}$, followed by 35 cycles of $30 \mathrm{sec}$ at $94^{\circ} \mathrm{C}, 1 \mathrm{~min}$ at $60^{\circ} \mathrm{C}$, and $2 \mathrm{~min}$ at $72^{\circ} \mathrm{C}$ with a final extension of $5 \mathrm{~min}$ of $72^{\circ} \mathrm{C}$. Each $13 \mathrm{iL}$ reaction contained 5-50 ng of DNA, $10 \mathrm{mM}$ Tris- $\mathrm{HCl}$ (pH 8.3), $50 \mathrm{mM} \mathrm{KCl}, 1.5 \mathrm{mM} \mathrm{MgCl}_{2}, 1.25 \mathrm{U}$ of Taq DNA polymerase (PerkinElmer - San Jose, CA), $150 \mathrm{mM}$ of each dNTP, and $0.3 \mathrm{mM}$ of each primer. After purification following the manufacturer's protocol (Applied Biosystems - Foster City, CA), direct sequencing was performed with an ABI 3100 automated sequencer (Applied Biosystems) at University of California Berkeley. Sequencing was performed in one direction only for all genes. The identity of the sequences was confirmed by comparing them with the National Center for Biotechnology Information (NCBI) BLASTn tool. 


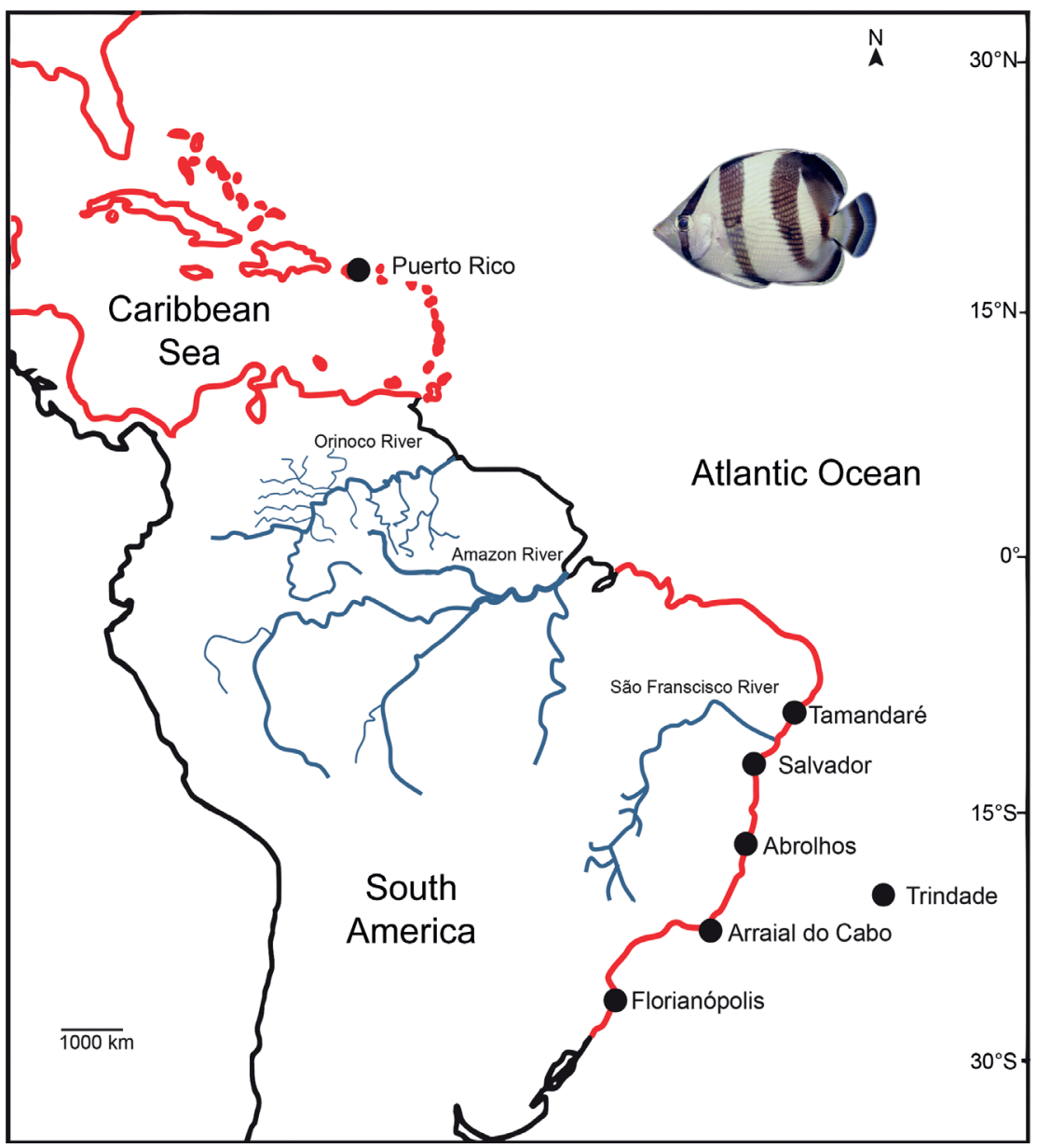

FIGURE 1 I Map with all sampling sites along Chaetodon striatus distribution range (red line). Blue color on the map indicates freshwater.

We used the computer program Geneious 5.0 (Biomatters) to align the sequences. Our alignments resulted in three matrices of $477 \mathrm{bp}, 789 \mathrm{bp}$ and $749 \mathrm{bp}$ for mitochondrial control region (122 sequences), cyt b (125 sequences) and rag 2 (105 diploid sequences, respectively). All analyses were performed with four datasets, each gene individually (control region, $c y t b$ and rag 2) and with both mtDNA markers concatenated (which resulted in a $1266 \mathrm{bp}$ fragment). Since we only obtained three individuals, from Trindade Island, they were only included in the haplotype network analyses.

Genetic diversity and evolutionary history. Genetic summary statistics as nucleotide and haplotype diversity, Tajima's D (Tajima, 1983) and Fu's Fs (Fu, 1997) neutrality tests were estimated for each population, as well as for all individuals in the program Arlequin version 3.5 (Excoffier, Lischer, 2010) and DnaSP (Rozas et al., 2003). Estimates of $\grave{E}$ (= 2 Íì, where ì is the mutation rate) were calculated for each population as well as for C. striatus as a whole. We used Fluctuate v.1.4 (Kuhner et al., 1998) to estimate the parameters È and $g$ (following procedures described in Bernardi, Lape, 2005 and Domingues et al., 2005). Analyses were repeated 10 times per region. Coalescence time was estimated by assuming that coalescence was reached when the population size was 
reduced to $1 \%$ of its present-day value. In order to estimate coalescence time, we used the mutation rate (i) as ì $=8.24-9.3$ for control region (Domingues et al., 2005) and $\grave{i}=$ 1.5-1.7 for $c y t b$ (Bernardi, Lape, 2005).

Neutrality analyses were performed with Tajimas's D (Tajima, 1989) and Fu's Fs (Fu, $\mathrm{Li}, 1993)$ for all datasets. In addition, the datasets were assessed for the most appropriate model of nucleotide substitution using the Akaike Information Criterion (AIC) as implemented in Modeltest 3.06 (Posada, Crandall, 1998). In addition, in order to analyse population size dynamics though time for both mtDNA loci combined, we used a Bayesian Skyline Plot method implemented in BEAST 2.0 (Drummond et al., 2005). This Bayesian approach incorporates the uncertainty in the genealogy by using MCMC integration under a coalescent model, where the timing of divergence dates provides information about effective population sizes through time. We used the evolutionary model suggested by Modeltest, a length chain of $10^{6}$ and the substitution rates described above. The mutation rate used for control region was $6.94-7.83 \%$ and $c y t b 2.36-2.67 \%$ per million years (Bernardi, Lape, 2005; Domingues et al., 2005).

Connectivity and structure between provinces and ecosystems. Genealogical relationships among haplotypes were estimated with a median-joining haplotype network using "Pegas" R package (Paradis, 2010). Population structure and gene flow were assessed with an analysis of molecular variance AMOVA (Excoffier et al., 1992) in the program Arlequin version 3.5. For this analysis, alternative scenarios of geographic/ ecosystem subdivision were used: 1) Caribbean (PR) vs. Brazilian Province (TAM, SAL, AB, AC, FLO) - for this, we ran ten AMOVAs with equal sample size, randomly subsampling Brazilian populations each time; 2) São Francisco River influence as an oceanographic barrier (PR, TAM vs. SAL, AB, AC, FLO); 3) coral reefs (PR, TAM, $\mathrm{SAL}$ and $\mathrm{AB}) v s$. rocky reefs (AC and FLO). Population pairwise Fst comparisons were calculated using the program Arlequin version 3.5, where statistical significance was obtained using 1,000 replicates. Migration between populations was estimated using Migrate version 2.0 (Domingues et al., 2005) and analyses were repeated 10 times to ensure stability of parameter estimates.

\section{RESULTS}

Genetic diversity and evolutionary history. The concatenated mtDNA alignment of Chaetodon striatus resulted in $1266 \mathrm{bp}$, with 65 phylogenetically informative positions and 110 haplotypes, low nucleotide diversity $(0.006 \pm 0.003)$, but high haplotype diversity $(0.99 \pm 0.001)$. Sequences generated for the nuclear rag 2 had 10 phylogenetically informative nucleotides and 42 haplotypes (Tab. 1). Low nucleotide diversity $(0.002 \pm$ $0.001)$ and high haplotype diversity $(0.76 \pm 0.02)$ were also found among individuals. Although nucleotide diversity was general low, Brazilian populations showed the highest values for the mitochondrial markers, while Puerto Rico, in the Caribbean, showed slightly higher values for the nuclear marker (Tab. 1). Yet, Puerto Rican population showed the highest number of haplotypes for both mitochondrial and nuclear genes, and the highest haplotype diversity for the nuclear gene (Tab. 1).

Population growth and coalescence times were estimated for C. striatus (Tab. 2). 
TABLE 1 I Summary statistics of Chaetodon striatus with rag 2 and mtDNA concatenated datasets. $n=$ number of individuals; h=number of haplotypes; hd= haplotype diversity and standard deviation; $\circlearrowright=$ nucleotide diversity and standard deviation; Tajima's D and Fu's F statistics.

\begin{tabular}{|c|c|c|c|c|c|c|}
\hline Concatenated mtDNA & $\mathrm{n}$ & $\mathrm{h}$ & hd (SD) & $\pi(\mathrm{SD})$ & Tajima's D & Fs \\
\hline Puerto Rico & 26 & 24 & $0.994(0.013)$ & $0.005(0.003)$ & -2.092 & -16.871 \\
\hline Tamandaré & 13 & 13 & $1.000(0.031)$ & $0.006(0.003)$ & -1.651 & -7.415 \\
\hline Salvador & 19 & 19 & $1.000(0.017)$ & $0.007(0.004)$ & -1.426 & -11.453 \\
\hline Abrolhos & 20 & 20 & $1.000(0.016)$ & $0.0012(0.0009)$ & -1.732 & -14.412 \\
\hline Arraial do Cabo & 20 & 19 & $0.955(0.018)$ & $0.008(0.004)$ & -1.853 & -11.156 \\
\hline Florianópolis & 19 & 19 & $1.000(0.017)$ & $0.0067(0.0036)$ & -1.980 & -12.788 \\
\hline Total & 120 & 110 & $0.998(0.001)$ & $0.006(0.003)$ & -2.372 & -180.561 \\
\hline \multicolumn{7}{|l|}{$\operatorname{rag} 2$} \\
\hline Puerto Rico & 42 & 13 & $0.823(0.04)$ & $0.0029(0.0018)$ & -1.307 & -4.761 \\
\hline Tamandaré & 24 & 8 & $0.692(0.095)$ & $0.0017(0.0012)$ & -0.974 & -3.408 \\
\hline Salvador & 34 & 9 & $0.731(0.063)$ & $0.0019(0.0013)$ & -1.208 & -3.12 \\
\hline Abrolhos & 40 & 8 & $0.714(0.064)$ & $0.0016(0.0011)$ & -0.665 & -2.48 \\
\hline Arraial do Cabo & 34 & 12 & $0.793(0.053)$ & $0.0021(0.0014)$ & -1.049 & -6.372 \\
\hline Florianópolis & 32 & 10 & $0.754(0.061)$ & $0.0022(0.0014)$ & -1.25 & -3.878 \\
\hline Total & 210 & 42 & $0.764(0.024)$ & $0.002(0.001)$ & -2.05 & -46.971 \\
\hline
\end{tabular}

Coalescence time of the entire population was estimated between 32 and 86 Kya. Individual populations show a range from 28 and $119 \mathrm{Kya}$ (Tab. 2). The Bayesian skyline plot (HKY + G model for both segments) and population growth values were consistent in showing a significant population size increase around 80-100 Kya (Fig. 2).

Connectivity and structure between provinces and ecosystems. Values of pairwise Fst among populations were generally low for all datasets and only the comparison between Puerto Rico and Abrolhos populations for the nuclear gene was statistically significant (Tab. 3). These results were reflected by haplotype networks not showing any obvious pattern of population structure (Fig. 3), including for the isolated population of Trindade Island. The mtDNA network had a star-like shape, where haplotypes were shared between different populations (Fig. 3A). One haplotype present only in Puerto Rico was found in the center of the network, potentially representing an ancestral haplotype. The rag 2 network had three most frequent haplotypes shared by all populations (Fig. 3b). AMOVA results for all scenarios showed that most of the genetic variance in mitochondrial and nuclear markers corresponded to differences within populations, with values between $98-100 \%$ (Tab. 4).

Migrate analyses showed a lack of directionality (Tab. 5), ranging from 61 to 823 migrants between sites for the concatenated mtDNA, and from 169 to 887 migrants for the rag 2. The comparison of migration between Caribbean and Brazil did not show an obvious directionality, with a slightly higher number of migrants from the Caribbean to Brazil for to the concatenated mtDNA markers, and an inverse pattern displayed by the nuclear rag 2. However, some sites showed higher values of emigration than immigration (Fig. 4A-B). In general, southern rocky reefs sites received more migrants than were exported, a pattern shared by the Caribbean population when considering the rag 2 gene (Fig. 4B). Brazilian sites with developed coral reef systems, such as Tamandaré and $A$ brolhos, showed higher rates of emigration than immigration (Fig. 4). 
TABLE 2 I Historical demography of Chaetodon striatus in the western Atlantic. Values of theta $(\Theta)$ are given when growth (g) is constant $(\Theta c)$ and $g$ is variable $(\Theta v)$. Times of coalescence in thousands of years are given in the right. Values in parentheses correspond to standard deviations.

\begin{tabular}{|c|c|c|c|c|}
\hline 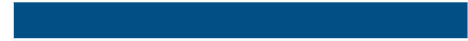 & $\Theta c$ & $\Theta \mathbf{v}$ & g & Coalescence $\left(10^{3}\right)$ \\
\hline \multicolumn{5}{|l|}{ cyt $b$} \\
\hline All samples & $0.0038(0.0011)$ & $\begin{array}{c}0.909 \\
(2.836)\end{array}$ & $\begin{array}{l}8322.1 \\
(2230)\end{array}$ & $32.5-36.8$ \\
\hline Puerto Rico & $\begin{array}{c}0.004 \\
(0.0006)\end{array}$ & $\begin{array}{c}0.239 \\
(0.303)\end{array}$ & $6540.1(2753.1)$ & $41.4-46.9$ \\
\hline Tamandaré & $0.0021(0.0002)$ & $\begin{array}{c}0.032 \\
(0.031)\end{array}$ & $\begin{array}{c}9491 \\
(1096.2)\end{array}$ & $28.5-32.3$ \\
\hline Salvador & $0.0034(0.0012)$ & $\begin{array}{c}2.105 \\
(5.741)\end{array}$ & 8385.1 (2199.7) & $32.3-36.6$ \\
\hline Abrolhos & $0.0041(0.0003)$ & $\begin{array}{c}1.614 \\
(2.909)\end{array}$ & 7880.5 (1785.2) & $34.3-38.9$ \\
\hline Arraial do Cabo & $0.0049(0.0002)$ & $\begin{array}{c}1.05 \\
(2.705)\end{array}$ & $\begin{array}{l}9014.3 \\
(2030)\end{array}$ & $30-34$ \\
\hline Florianópolis & $0.0043(0.0003)$ & $\begin{array}{l}0.413 \\
(0.33)\end{array}$ & $8621.8(2402.4)$ & $31.4-35.6$ \\
\hline \multicolumn{5}{|l|}{ Control region } \\
\hline All Samples & $0.0747(0.0141)$ & $\begin{array}{c}1.742 \\
(1.336)\end{array}$ & $\begin{array}{c}645.4 \\
(146.5)\end{array}$ & $76.6-86.5$ \\
\hline Puerto Rico & $0.0878(0.0029)$ & $\begin{array}{c}2.977 \\
(2.256)\end{array}$ & $\begin{array}{l}728.9 \\
(110)\end{array}$ & $67.9-76.6$ \\
\hline Tamandaré & $\begin{array}{l}0.0486 \\
(0.001)\end{array}$ & $\begin{array}{c}1.959 \\
(1.511)\end{array}$ & $\begin{array}{c}826.9 \\
(143.9)\end{array}$ & $59.8-67.5$ \\
\hline Salvador & $0.0879(0.0028)$ & $\begin{array}{c}1.033 \\
(0.217)\end{array}$ & $\begin{array}{l}469.3 \\
(47.7)\end{array}$ & $105.4-119$ \\
\hline Abrolhos & $0.0662(0.0016)$ & $\begin{array}{c}0.762 \\
(0.243)\end{array}$ & $\begin{array}{l}555.3 \\
(93.8)\end{array}$ & $89.1-100.5$ \\
\hline Arraial do Cabo & $0.0772(0.0029)$ & $\begin{array}{c}2.118 \\
(0.613)\end{array}$ & $\begin{array}{l}675.1 \\
(64.3)\end{array}$ & $73.3-82.7$ \\
\hline Florianópolis & $0.0806(0.0024)$ & $\begin{array}{c}1.601 \\
(0.542)\end{array}$ & $\begin{array}{l}616.9 \\
(54.1)\end{array}$ & $80.2-90.5$ \\
\hline
\end{tabular}

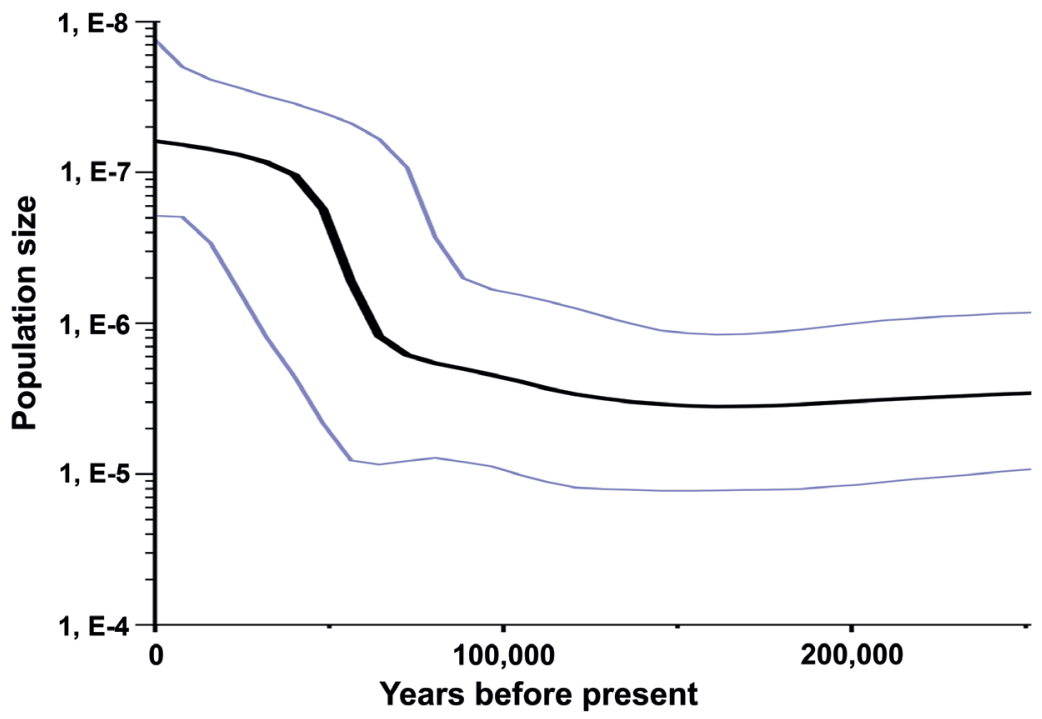

FIGURE 2 I Bayesian skyline plot showing the effective population size fluctuation through time (black line, median estimation; purple lines, confidence interval). 
TABLE 3 I Pairwise Fst values for Chaetodon striatus populations in the western Atlantic, where above the diagonal are values for the concatenated mtDNA, while below the diagonal are rag 2 values. Statistical significant values are in bold.

\begin{tabular}{|r|c|c|c|c|c|c|}
\hline & Puerto Rico & Tamandaré & Salvador & Abrolhos & Arraial do Cabo & Florianópolis \\
\hline Puerto Rico & - & 0.011 & 0.010 & -0.006 & -0.002 & 0.001 \\
\hline Tamandaré & 0.016 & - & 0.019 & -0.012 & 0.014 \\
Salvador & 0.009 & -0.021 & - & -0.001 & -0.001 & -0.012 \\
\hline Abrolhos & 0.033 & -0.022 & -0.005 & - & -0.002 & -0.007 \\
Arraial do Cabo & -0.009 & -0.005 & -0.017 & 0.005 & -0.002 \\
\hline Florianópolis & -0.009 & -0.012 & -0.010 & 0.003 & -0.011 \\
\hline
\end{tabular}

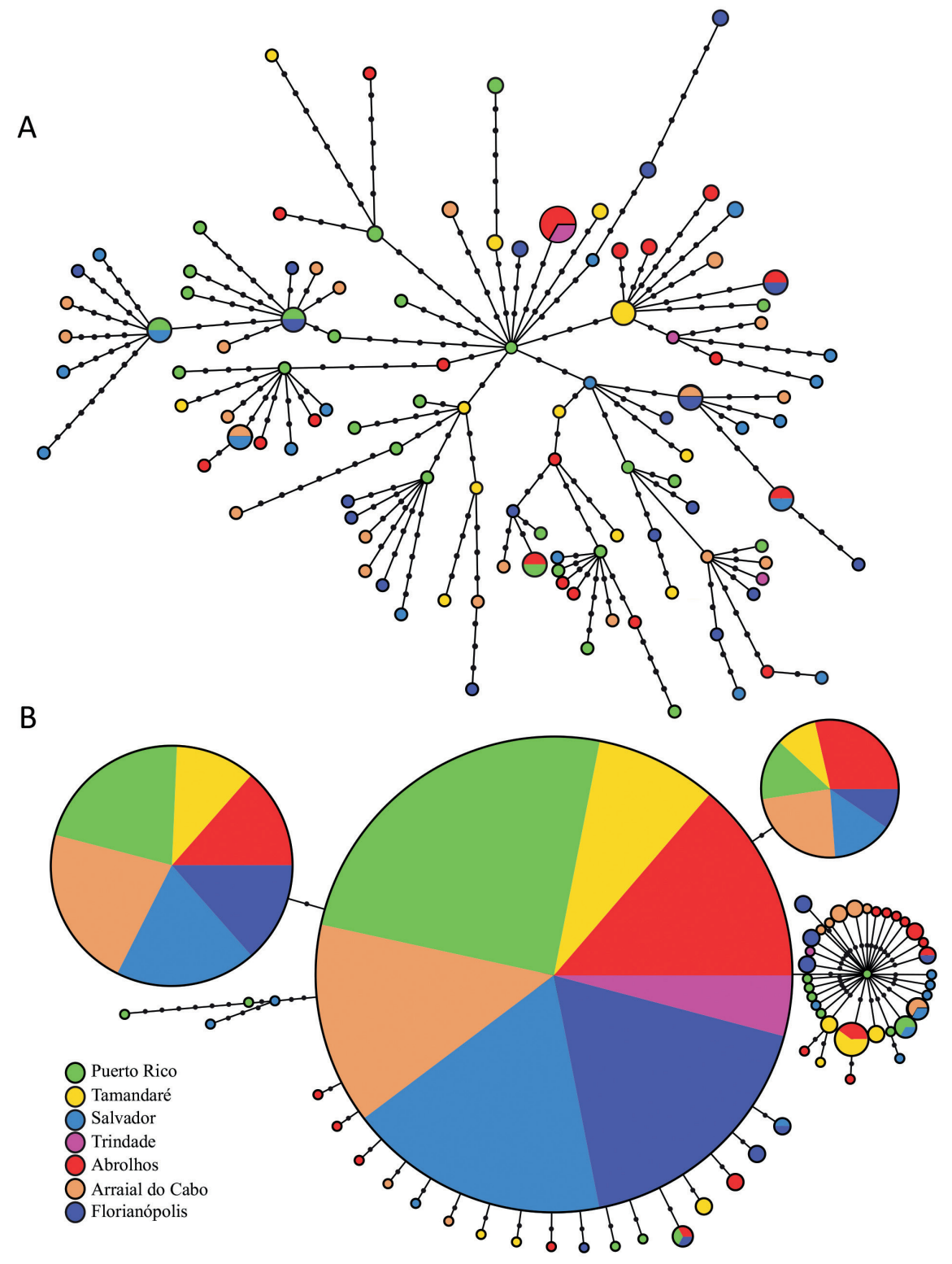

FIGURE 3 । Median-joining haplotype network with two datasets: A. mtDNA concatenated (control region and cyt $b$ ); B. rag 2. Each color represents one population. Black nodes mean mutational steps. 
TABLE 4 I Hierarchical analysis of molecular variance (AMOVA) used to estimate levels of genetic differentiation among groups (Фct), among populations within groups (Фsc) and within populations (Фst).

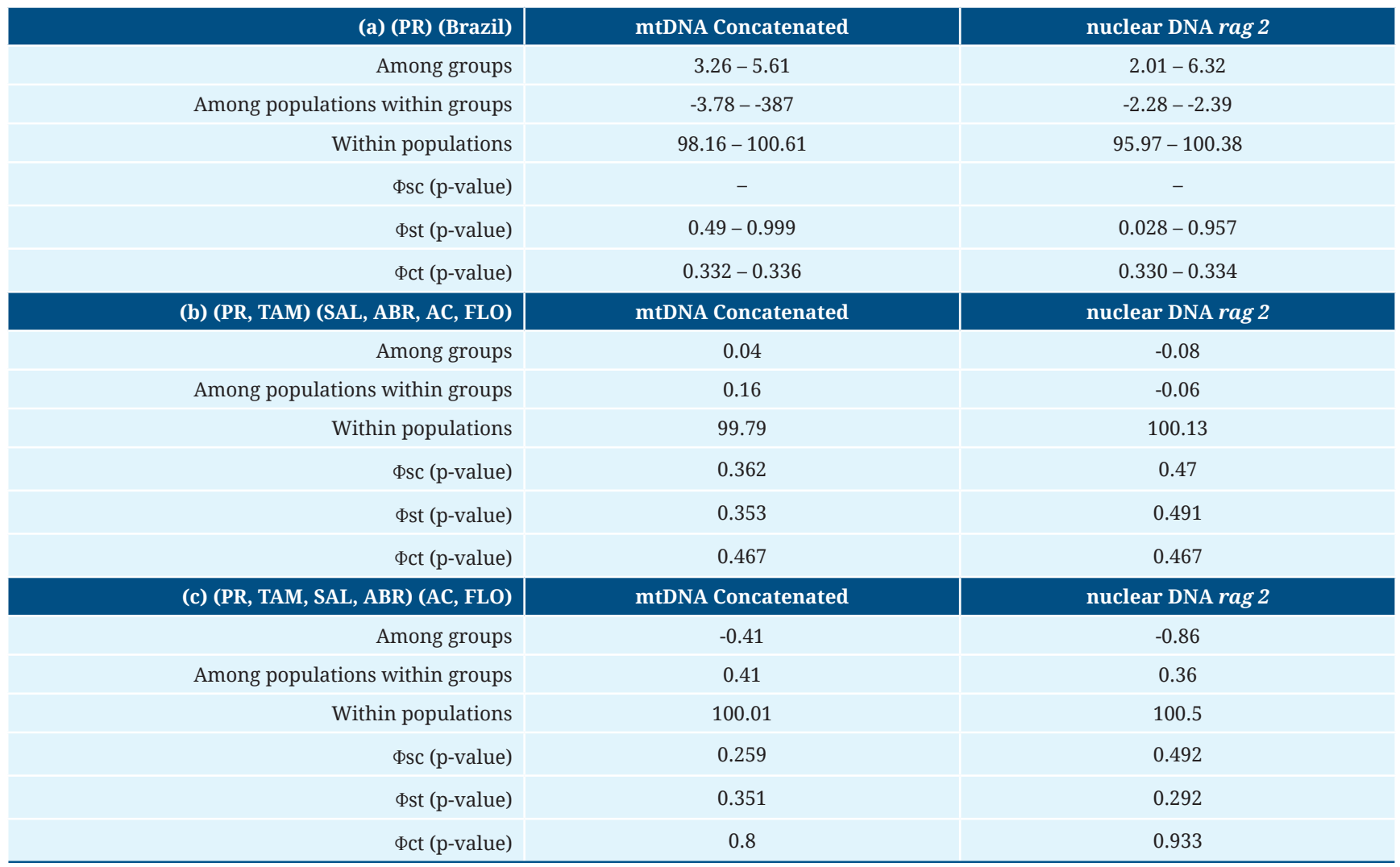

TABLE 5 I Migrate data for the mtDNA concatenated and rag 2 datasets of Chaetodon striatus along the western Atlantic.

\begin{tabular}{|c|c|c|c|c|c|c|c|}
\hline & \multicolumn{7}{|c|}{ Emigration (From) } \\
\hline & $\begin{array}{c}\text { mtDNA } \\
\text { concatenated }\end{array}$ & Puerto Rico & Tamandaré & Salvador & Abrolhos & Arraial do Cabo & Florianópolis \\
\hline \multirow{13}{*}{$\begin{array}{c}\text { Immigration } \\
\text { (receiving) }\end{array}$} & Puerto Rico & - & $694.1(226.3)$ & $467.5(380.3)$ & $605.5(364.2)$ & $288.5(381.2)$ & $61.1(24.5)$ \\
\hline & Tamandaré & $186.9(257.1)$ & - & $290.8(353.1)$ & 564.1 (397) & $175.9(245.4)$ & $615.8(389.8)$ \\
\hline & Salvador & 436.6 (397) & $589.4(365.9)$ & - & $559.3(389.8)$ & $491.5(398.4)$ & $459.9(428.2)$ \\
\hline & Abrolhos & 318.7 (393.2) & $411.6(389.5)$ & $435.8(367.6)$ & - & 223.6 (350.9) & $226.9(346.2)$ \\
\hline & Arraial do Cabo & $602.3(362.9)$ & $750.2(242.8)$ & 479.1 (397.1) & 720.9 (312.4) & - & $297.8(392.8)$ \\
\hline & Florianópolis & $823.3(22)$ & $296.6(357.8)$ & $446.7(324)$ & $696.1(284.2)$ & $623.9(353.5)$ & - \\
\hline & $\operatorname{rag} 2$ & & & & & & \\
\hline & Puerto Rico & - & $858(10.6)$ & $874.1(27)$ & $863.1(17.2)$ & 792.5 (193.5) & $818.8(65.8)$ \\
\hline & Tamandaré & $169.3(55.6)$ & - & $398.9(173.8)$ & $716.3(115.3)$ & $268.3(180.2)$ & $199.8(61.8)$ \\
\hline & Salvador & 408.7 (135.4) & 862.5 (28.7) & - & $858.1(28.7)$ & $575.2(132.7)$ & $555.5(85.8)$ \\
\hline & Abrolhos & $171.3(46.2)$ & 716.9 (82.9) & $528.8(185.7)$ & - & $296.3(114.2)$ & $270.3(83.3)$ \\
\hline & Arraial do Cabo & $655.6(140.4)$ & $808.6(206.4)$ & $840.2(38.7)$ & $879.2(22.6)$ & - & $688(197.6)$ \\
\hline & Florianópolis & 522.6 (154) & $880.2(12.2)$ & 862 (51.9) & $887.4(20.6)$ & 750.3 (90.7) & - \\
\hline
\end{tabular}




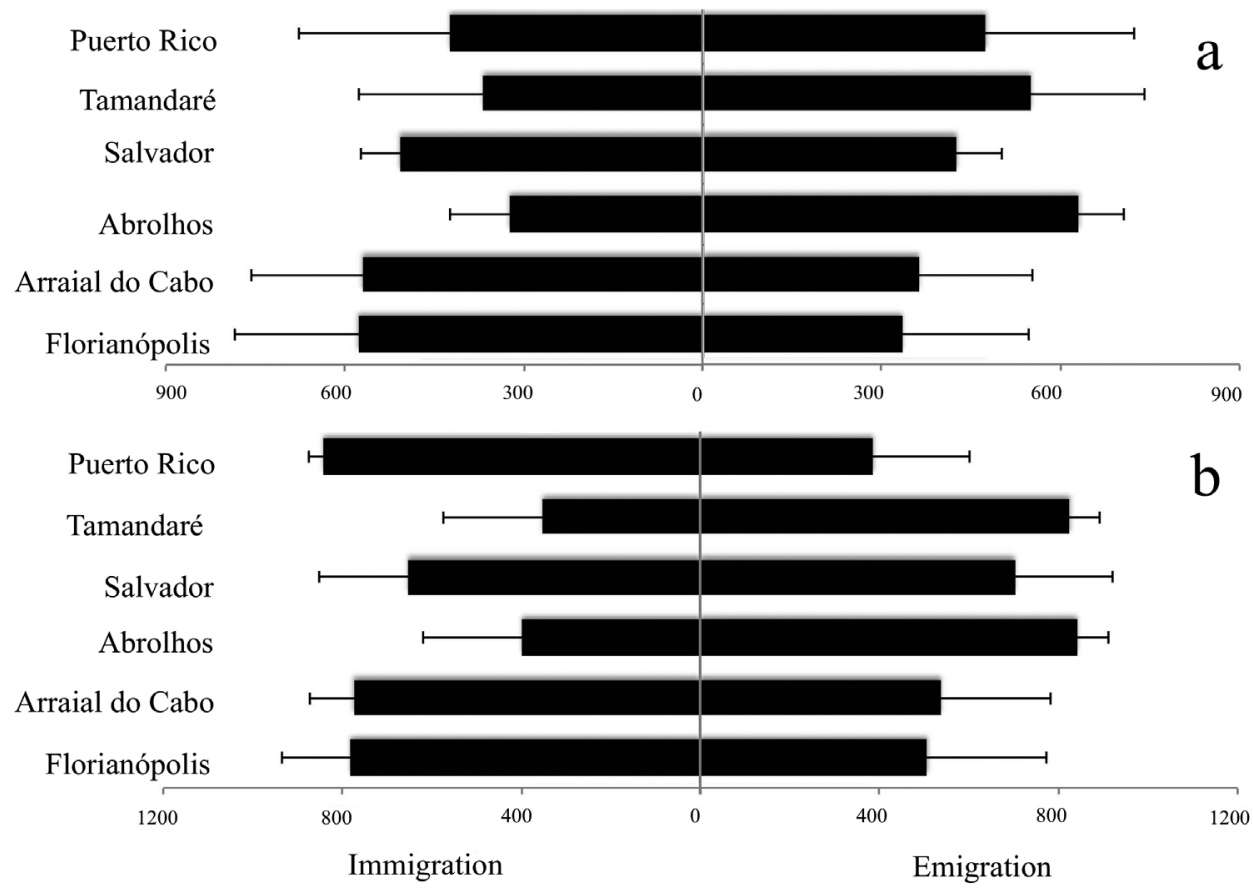

FIGURE 4 I Migrate values (number of individuals) and error bars (standard error) of immigration and emigration of individuals of Chaetodon striatus per studied population in the western Atlantic: A. mtDNA concatenated (control region and cyt $b$ ) and B. rag 2.

\section{DISCUSSION}

The genetic diversity of Chaetodon striatus showed a pattern of low nucleotide diversity and high haplotype diversity, where most of the genetic differences were present among individuals from the same locality. As for other widespread Atlantic reef fishes (Rocha et al., 2008; Silva et al., 2015), these results suggest high connectivity among populations, which is also supported by low Fst values and a lack of genetic structure between provinces and ecosystems. In addition to relatively long PLDs, butterflyfish larvae display an impressive swimming ability prior to settlement, which may increase their dispersal potential (Stobutzki, Bellwood, 1997; Fisher, 2005; Leis, Yerman, 2012). This characteristic may favor the wide distribution of the butterflyfish species, leading to high population connectivity and ecological plasticity.

Moreover, we found evidence for a recent population expansion. Based on neutrality tests performed for all datasets, Tajima's D and Fu's Fs were negative and non-significant for all populations, and coalescence and Bayesian skyline plot analyses indicated that the population expansion began around 30-120 thousand years ago, all corroborating to the recent population expansion scenario. These results are similar to previous studies on coral reef fishes (Ludt, Rocha, 2015), where sea level fluctuation due to Pleistocene glaciations changed the habitat availability and consequently population size of several shallow water reef fishes (Ludt et al., 2012). Pleistocene sea level low-stands reduced the Caribbean coral reef area by up to $92 \%$, increasing the strength of the Orinoco/Amazon barrier and the isolation of the Brazilian Province (Ludt, Rocha, 2015). However, 
the central haplotype (potential ancestral) found in the Puerto Rican population may corroborate recent findings that point to the fact that the impact of sea level low-stand was stronger in the southwestern Atlantic (Pinheiro et al., 2017, 2018). The tropical Brazil accounts for less than 5\% of the western Atlantic reef area (Moura, 2000), and is largely influenced by riverine discharge, offering rough conditions for coral reef fishes during these unfavorable times. Habitat persistence during periods of climate change has been proposed as one of the main factors for preserving marine biodiversity (Pellissier et al., 2014) and it may explain the greater reef fish richness found in the Caribbean compared to the Brazilian Province (Floeter et al., 2008; Pinheiro et al., 2018).

Differently to our predictions, and consistent with results obtained for many other fish species from other families (Rocha, 2003; Rocha et al., 2015), neither the Orinoco/ Amazon outflow barrier (Rocha, 2003; Floeter et al., 2008), the São Francisco River (Cunha et al., 2014), the remoteness of oceanic islands (Neves et al., 2016; Pinheiro et al., 2017; Dias et al., 2019) nor the ecosystem divergence (coral vs. rocky reefs; Floeter et al., 2008; Pinheiro et al., 2018) resulted in population structure in the western Atlantic. Although the lack of structure could indicate limited time to divergence, high levels of migration seem to be the main driver connecting all populations of C. striatus. Most of species that display deep lineages divergence and speciation between the Caribbean and Brazil are smaller and inhabit shallower waters than C. striatus (Pinheiro et al., 2018). These high migration rates suggest that C. striatus might be also connected to other Greater Caribbean sub-provinces (Gulf of Mexico and USA East Coast) not assessed in this study (Robertson, Cramer, 2014), despite the very low abundance of the species in such regions (Jeffrey et al., 2001; Robertson et al., 2016).

Interestingly, the high contribution of migrants from the peripheral Brazilian Province to the Caribbean has also been found in other studies (Rocha et al., 2008). Migration is strong enough to overcome the species distributional gap existent in the large area influenced by the Amazon-Orinoco Plume (Fig. 1), a region also affected by vortices that cause retroreflection (NASA, 2013). This phenomenon is driven by the North Brazilian Current, which derives from the South Equatorial Current, running from the eastern coast of Brazil towards the Caribbean. On the other hand, the high connectivity among all analyzed populations indicates that the main coastal currents found along the western Atlantic are flexible to the counter-flow of migrants. Thus, the multi-directionality in larvae migration and the permeability of geographic barriers allow both genetic homogeneity in widespread species (as shown in this study) as well as vagrant dispersal events of provincial species (Freitas et al., 2014).

As a generalist zoobenthivore, C. striatus presents high dietary plasticity, and does not have differences in density and foraging rates or nutritional conditions along its distribution range (Liedke et al., 2016). Our results are consistent with the idea that C. striatus may have evolved sufficient ecological plasticity in the western Atlantic, to enable that species to colonize the largest latitudinal gradient for an Atlantic butterflyfish, encompassing 44 degrees of latitude, and this is reflected in broad genetic signatures over its entire range. 


\section{ACKNOWLEDGMENTS}

Financial support was provided by CNPq through the Grants MCT-Jovens Pesquisadores (\#571295/2008-8), Universal (483682/2010-1) and SISBIOTA-MAR (CNPq 563276/2010-0 and FAPESC 6308/2011-8). We would like to thank all people that helped during fieldwork and logistics: Daniel Almeida, Yvette Alva-Campbell, Diego R. Barneche, Antonio B. Anderson, Alecio Bernardi, Alexis Jackson, Lais Chaves, Mattew Craig, Daniel F. Dinslaken, João Lucas Feitosa, Carlos Eduardo Leite Ferreira, João Luiz Gasparini, Jean Christophe Joyeux, João Paulo Krajewski, Alberto Lindner, Guilherme O. Longo, Rafael Macieira, Eric Mazzei, Renata Mazzei, Thiago Mendes, João Anchieta Nunes, Pedro H Pereira, Marloes Poortvliet, Juan Pablo Quimbayo, Cláudio Sampaio, Duane Sanabria, Thiony Simon (in memoriam), Julia Souza, Kimberly Tenggardjaja. We also thank Nelson Fagundes, Andrea Turchetto and Thiony Simon (in memoriam) for insights and discussions in an earlier manuscript draft, and Eva Salas and Eric Garcia for contribution in the data analyses. Ana MR Liedke was granted a scholarship from CAPES, Brazilian Ministry Educational Council, and Hudson T Pinheiro from CNPq (Ciência sem Fronteiras; GDE 202475/2011-5).

\section{REFERENCES}

- Alwany MA, Stachowitsch M, Hanafy MH, Gab-Alla AAFA. Food preferences of the Butterflyfish Chaetodon melannotus on the reef flat in Sharm El-Sheikh, Egypt. J Fish Aquat Sci. 2007; 2(1):38-46. http:// dx.doi.org/10.3923/jfas.2007.38.46

- Anderson AB, Carvalho-Filho A, Morais RA, Nunes LT, Quimbayo JPA, Floeter SR. Brazilian tropical fishes in their southern limit of distribution: checklist of Santa Catarina's rocky reef ichthyofauna, remarks and new records. Check List. 2015; 11(4):1688. http://dx.doi. org/10.15560/11.4.1688

- Bernardi G, Lape J. Tempo and mode of speciation in the Baja California disjunct fish species Anisotremus davidsonii. Mol Ecol. 2005; 14(13):4085-96. https://doi. org/10.1111/j.1365-294X.2005.02729.x

- Booth DJ, Parkinson K. Pelagic larval duration is similar across $23^{\circ}$ of latitude for two species of butterflyfish (Chaetodontidae) in eastern Australia. Coral Reefs. 2011; 30:1071. https://doi. org/10.1007/s00338-011-0815-6

- Carvalho-Filho A. Peixes: costa brasileira. 3rd ed. São Paulo: Editora Melro; 1999.
- Craig MT, Eble JA, Bowen BW. Origins, ages, and population histories: comparative phylogeography of endemic Hawaiian butterflyfishes (genus Chaetodon). J Biogeogr. 2010; 37(11):212536. https://doi.org/10.1111/j.13652699.2010.02358.x

- Cunha IMC, Souza AS, Dias EA, Amorim KDJ, Soares RX, Costa GWWF, GarcíaMachado E, Galetti PM, Molina WF. Genetic multipartitions based on d-loop sequences and chromosomal patterns in brown Chromis, (Pomacentridae), in the western Atlantic. Biomed Res Int. 2014; 2014:254698. https://doi. org/10.1155/2014/254698

- Dias RM, Lima SMQ, Mendes LF, Almeida DF, Paiva PC, Britto MR. Different speciation processes in a cryptobenthic reef fish from the Western Tropical Atlantic. Hydrobiologia, 2019; 837:133-47. https://doi.org/10.1007/s10750-019-3966-Z

- DiBattista JD, Rocha LA, Craig MT, Feldheim KA, Bowen BW. Phylogeography of two closely related Indo-Pacific butterflyfish reveal divergent evolutionary histories and discordant results from mtDNA and microsatellites. J Hered. 2012; 103(5):617-29. https://doi.org/10.1093/ jhered/ess056 
- Domingues VS, Bucciarelli G, Almada VC, Bernardi G. Historical colonization and demography of the Mediterranean damselfish, Chromis chromis. Mol Ecol. 2005; 14(13):4051-63. https://doi. org/10.1111/j.1365-294X.2005.02723.x

- Drummond AJ, Rambaut A, Shapiro B, Pybus OG. Bayesian coalescent inferene of past population dynamics from molecular sequences. Mol Biol Evol. 2005; 22(15):118592. https://doi.org/10.1093/molbev/msi103

- Eble JA, Bowen BW, Bernardi G. Phylogeography of coral reef fishes. In: Mora C, editor. Ecology of fishes on coral reefs. Cambridge University Press; 2015. p. 64-75. https://doi.org/10.1017/ CB09781316105412.009

- Eckert CG, Samis KE, Lougheed SC. Genetic variation across species' geographical ranges: The central-marginal hypothesis and beyond. Mol Ecol. 2008; 17(5):1170-88. https://doi.org/10.1111/ j.1365-294X.2007.03659.x

- Excoffier L, Smouse PE, Quattro JM. Analysis of molecular variance inferred from metric distances among DNA haplotypes: Application to human mitochondrial DNA restriction data. Genetics. 1992; 131(2):479-91.

- Excoffier L, Lischer HE. Arlequin suite ver 3.5: A new series of programs to perform population genetics analyses under Linux and Windows. Mol Ecol Resour. 2010; 10(3):564-67. https://doi. org/10.1111/j.1755-0998.2010.02847.x

- Floeter SR, Rocha LA, Robertson DR, Joyeux JC, Smith-Vaniz WF, Wirtz P, Edwards AJ, Barreiros JP, Ferreira CEL, Gasparini JL, Brito A, Falcón JM, Bowen BW, Bernardi G. Atlantic reef fish biogeography and evolution. J Biogeogr. 2008; 35(1):22-47. https://doi.org/10.1111/ j.1365-2699.2007.01790.x

- Fisher R. Swimming speeds of larval coral reef fishes: Impacts on self-recruitment and dispersal. Mar Ecol Prog Ser. 2005; 285:22332. https://doi.org/10.3354/meps285223

- Freitas R, Luiz OJ, Silva PN, Floeter SR, Bernardi G, Ferreira CEL. The occurrence of Sparisoma frondosum (Teleostei: Labridae) in the Cape Verde Archipelago, with a summary of expatriated Brazilian endemic reef fishes. Mar Biodivers. 2014; 44:173-79. https://doi.org/10.1007/s12526-013-0194-z
- Fu YX. Statistical tests of neutrality of mutations against population growth, hitchhiking and background selection. Genetics. 1997; 147(2):915-25.

- Fu YX, Li WH. Statistical tests of neutrality of mutations. Genetics 1993; 133(3):693709.

- Jeffrey CFG, Pattengill-Semmens C, Gittings S, Monaco ME. Distribution and sighting frequency of reef fishes in the Florida Keys National Marine Sanctuary. Marine Sanctuaries Conservation Series MSD-01-1 [Internet]. U.S. Department of Commerce, National Oceanic and Atmospheric Administration, Marine Sanctuaries Division. Silver Spring; 2001.

- Jones GP, Srinivasan M, Almany GR. Population connectivity and conservation of marine biodiversity. Oceanography. 2007; 20(3):100-11. https://doi.org/10.5670/ oceanog.2007.33

- Kuhner MK, Yamato J, Felsenstein J. Maximum likelihood estimation of population growth rates based on the coalescent. Genetics. 1998; 149(1):429-34.

- Lawton RJ, Cole AJ, Berumen ML, Pratchett MS. Geographic variation in resource use by specialist versus generalist butterflyfishes. Ecography. 2011; 35(6):566-76. https://doi.org/10.1111/j.16000587.2011.07326.x

- Lee WJ, Conroy J, Howell WH, Kocher TD. Structure and evolution of teleost mitochondrial control regions. J Mol Evol. 1995; 41:54-66. https://doi.org/10.1007/ BF00174041

- Leis JM. The pelagic stage of reef fishes: The larval biology of coral reef fishes. In: Sale PF, editor. The ecology of fishes on coral reefs. San Diego: Academic Press; 1991. p.183-230. https://doi.org/10.1016/ B978-0-08-092551-6.50013-1

- Leis JM, Yerman MN. Behavior of larval butterflyfishes (Teleostei: Chaetodontidae) at settlement on coral reefs. Copeia. 2012; 2012(2):211-21. https://doi.org/10.1643/CE10-185 
- Liedke AMR, Barneche DR, Ferreira CEL, Segal B, Nunes LT, Burigo AP, Carvalho JA, Buck S, Bonaldo RM, Floeter SR. Abundance, diet, foraging and nutritional condition of the banded butterflyfish (Chaetodon striatus) along the western Atlantic. Mar Biol. 2016; 163:6. https://doi.org/10.1007/s00227-0152788-4

- Liedke AMR, Bonaldo RM, Segal B, Ferreira CEL, Nunes LT, Burigo AP, Buck S, Oliveira-Santos LGR, Floeter SR. Resource partitioning by two syntopic sister-species of butterflyfish (Chaetodontidae). J Mar Biol Assoc UK. 2018; 98(7):1767-73. https://doi.org/10.1017/ S0025315417001321

- Ludt WB, Bernal MA, Bowen BW, Rocha LA. Living in the past: Phylogeography and population histories of Indo-Pacific Wrasses (Genus Halichoeres) in shallow lagoons versus outer reef slopes. PLOS One. 2012; 7(6):e38042. https://doi. org/10.1371/journal.pone.0038042

- Ludt WB, Rocha LA. Shifting seas: The impacts of Pleistocene sea-level fluctuations on the evolution of tropical marine taxa. J Biogeogr. 2015; 42(1):25-38. https://doi.org/10.1111/jbi.12416

- Luiz OJ, Floeter SR, Rocha LA, Ferreira CEL. Perspectives for the lionfish invasion in the South Atlantic: Are Brazilian reefs protected by the currents? Mar Ecol Prog Ser. 2013; 485:1-7. https://doi.org/10.3354/ meps10383

- McMillan WO, Weigt LA, Palumbi SR. Color pattern evolution, assortative mating, and genetic differentiation in brightly colored butterflyfishes (Chaetodontidae). Evolution. 1999; 53(1):247-60. https://doi. org/10.1111/j.1558-5646.1999.tb05350.x

- Messmer V, Jones GP, Munday PL, Planes S. Concordance between genetic and species diversity in coral reef fishes across the Pacific Ocean biodiversity gradient. Evolution. 2012; 66(12):3902-17. https://doi. org/10.1111/j.1558-5646.2012.01725.x

- Moura RL. Brazilian reefs as priority areas for biodiversity conservation in the Atlantic ocean. In: Moosa MK, Soemodihardjo S, Soegiarto A, Romimohtarto K, Nontji A, Soekarno, Suharsono, editors. Proceedings of the Ninth International Coral Reef Symposium: Volume 2. Bali; 2000. p.917-20.
- NASA. SVS: Global sea surface currents and temperature [Internet]. USA: NASA/ Goddard Space Flight Center Scientific Visualization Studio; 2013. Available from: http://svs.gsfc.nasa.gov/3912

- Nelson JS. Fishes of the world. 4th ed. New York: Wiley; 2006.

- Neves JMM, Lima SMQ, Mendes LF, Torres RA, Pereira RJ, Mott T. Population structure of the rockpool blenny Entomacrodus vomerinus shows sourcesink dynamics among ecoregions in the tropical Southwestern Atlantic. PLOS One. 2016; 11(6):e0157472. https://doi. org/10.1371/journal.pone.0157472

- Palumbi SR. Marine Reserves: A tool for ecosystem management and conservation. Arlington: Pew Oceans Commission; 2003.

- Palumbi SR. Marine reserves and ocean neighborhoods: The spatial scale of marine populations and their management. Annu Rev Env Resour. 2004; 29:31-68. https://doi.org/10.1146/annurev. energy.29.062403.102254

- Paradis E. Pegas: An R package for population genetics with an integratedmodular approach. Bioinformatics. 2010; 26(3):419-20. https://doi.org/10.1093/ bioinformatics/btp696

- Pellissier L, Leprieur F, Parravicini V, Cowman PF, Kulbicki M, Litsios G, Olsen SM, Wisz MS, Bellwood DR, Mouillot D. Quaternary coral reef refugia pre-served fish diversity. Science. 2014; 344(6187):1016-19. https://doi.org/10.1126/ science. 1249853

- Pinheiro HT, Bernardi G, Simon T, Joyeux JC, Macieira RM, Gasparini JL, Rocha C, Rocha LA. Island biogeography of marine organisms. Nature. 2017; 549:8285. https://doi.org/10.1038/nature23680

- Pinheiro HT, Rocha LA, Macieira RM, Carvalho-Filho A, Anderson AB, Bender MG, DiDario F, Ferreira CEL, Figueiredo-Filho J, Francini-Filho R, Gasparini JL, Joyeux JC, Luiz OJ, Mincarone MM, Moura RL, Nunes JACC, Quimbayo JP, Rosa RS, Sampaio CLS, Sazima I, Simon T, Vila-Nova DA, Floeter SR. Southwestern Atlantic reef fishes: Zoogeographic patterns and ecological drivers reveal a secondary biodiversity center in the Atlantic Ocean. Divers Distrib. 2018; 24(7):951-65. https://doi. org/10.1111/ddi.12729 
- Planes S. Genetic diversity and dispersal capabilities in marine fish. Evol Biol. 1998; 30:253-98. https://doi.org/10.1007/978-14899-1751-5_7

- Pratchett MS, Berumen ML, Kapoor BG, editors. Biology of butterflyfishes. Boca Raton: CRC Press; 2014.

- Posada D, Crandall KA. Model Test: Testing the model of DNA substitution. Bioinformatics. 1998; 14(9):817-18. https:// doi.org/10.1093/bioinformatics/14.9.817

- Robertson DR, Cramer KL. Defining and dividing the greater Caribbean: Insights from the biogeography of shorefishes. PLOS One. 2014; 9(7):e102918. https://doi. org/10.1371/journal.pone.0102918

- Robertson DR, Perez-España H, Lara EN, Itza FP, Simões N. The fishes of Cayo Arcas (Campeche Bank, Gulf of Mexico): An updated checklist. ZooKeys. 2016; 640:139-55. https://doi.org/10.3897/ zookeys.640.10862

- Rocha LA. Patterns of distribution and processes of speciation in Brazilian reef fishes. J Biogeogr. 2003; 30(8):116171. https://doi.org/10.1046/j.13652699.2003.00900.x

- Rocha LA, Robertson DR, Roman J, Bowen BW. Ecological speciation in tropical reef fishes. Proc R Soc B. 2005; 272(1563):573-79. https://doi.org/10.1098/2004.3005

- Rocha LA, Rocha CR, Robertson DR, Bowen BW. Comparative phylogeography of Atlantic reef fishes indicates both origin and accumulation of diversity in the Caribbean. BMC Evol Biol. 2008; 8:157. https://doi.org/10.1186/1471-2148-8-157

- Rocha LA, Rocha CR, Baldwin CC, Weigt LA, McField M. Invasive Lionfish preying on critically endangered reef fish. Coral Reefs. 2015; 34:803-06. https://doi. org/10.1007/s00338-015-1293-z

- Rozas J, Sánchez-DelBarrio JC, Messeguer X, Rozas R. Dnasp, DNA polymorphism analyses by the coalescent and other methods. Bioinformatics. 2003; 19(18):2496-97. https://doi.org/10.1093/ bioinformatics/btg359
- Sambrook J, Russell DW. Molecular cloning: A laboratory manual. 3rd ed. New York: Cold Spring Harbor; 2001.

- Santos S, Hrbek T, Farias IP, Schneider H, Sampaio I. Population genetic structuring of the king weakfish, Macrodon ancylodon (Sciaenidae), in Atlantic coastal waters of south America: Deep genetic divergence without morphological change. Mol Ecol. 2006; 15(14):4361-73. https://doi. org/10.1111/j.1365-294X.2006.03108.x

- Selkoe KA, Toonen RJ. Marine connectivity: A new look at pelagic larval duration and genetic metrics of dispersal. Mar Ecol Prog Ser. 2011; 436:291-305. https://doi.org/10.3354/meps09238

- Silva R, Veneza I, Sampaio I, Araripe J, Schneider H, Gomes G. High levels of genetic connectivity among populations of Yellowtail Snapper, Ocyurus chrysurus (Lutjanidae - Perciformes), in the Western South Atlantic revealed through multilocus analysis. PLOS One. 2015; 10(3):e0122173. https://doi.org/10.1371/journal. pone.0122173

- Stobutzki IC, Bellwood DR. Sustained swimming abilities of late pelagic stage coral reef fishes. Mar Ecol Prog Ser. 1997; 149(1/3):35-41. https://doi.org/10.3354/ meps149035

- Tajima F. Evolutionary relationship of DNA sequences in finite populations. Genetics. 1983; 105(2):437-60.

- Tajima F. Statistical method for testing the neutral mutation hypothesis by DNA polymorphism. Genetics. 1989; 123(3):58595.

- Van Tassell JL, Joyeux JC, Macieira RM, Tornabene L. Status of Gobiosoma (Teleostei: Gobiidae) from Brazil: description of a new species, redescription of $G$. hemigymnum, molecular phylogeny of the genus, and key to Atlantic species. Zootaxa. 2015; 4007(4):451-80. http:// dx.doi.org/10.11646/zootaxa.4007.4.1

\section{AUTHOR CONTRIBUTIONS}

Ana M.R. Liedke: Conceptualization, Formal Analysis, Investigation, Methodology, Project administration, Validation, Visualization, Writing (original draft), Writing (review \& editing). 


\section{Neotropical Ichthyology}
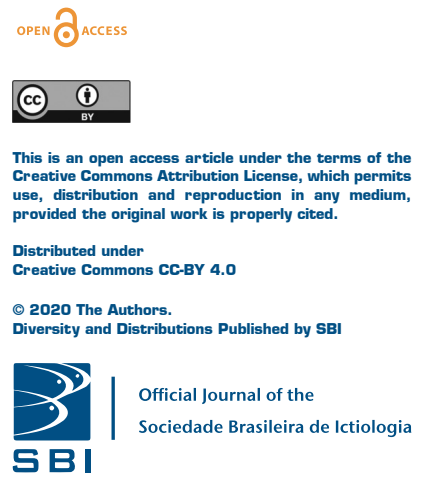

Hudson T. Pinheiro: Formal Analysis, Methodology, Validation, Visualization, Writing (original draft), Writing (review \& editing).

Sergio R. Floeter: Conceptualization, Funding acquisition, Investigation, Resources, Supervision, Validation, Visualization, Writing (review \& editing).

Giacomo Bernardi: Conceptualization, Formal Analysis, Investigation, Methodology, Supervision, Validation, Writing (review \& editing).

\section{ETHICAL STATEMENT}

Collecting permits: SISBIO \# 22637-1, SISBIO \# 21422-2, and SISBIO \# 12543-1.

\section{COMPETING INTERESTS}

Not applicable.

\section{HOW TO CITE THIS ARTICLE}

- Liedke AMR, Pinheiro HT, Floeter SR, Bernardi G. Phylogeography of the banded butterflyfish, Chaetodon striatus, indicates high connectivity between biogeographic provinces and ecosystems in the western Atlantic. Neotrop Ichthyol. 2020; 18(1):e190054. https://doi.org/10.1590/1982-0224-2019-0054 
